\title{
UAV-DEMs for Small-Scale Flood Hazard Mapping
}

\author{
Antonio Annis $1, *\left(\mathbb{0}\right.$, Fernando Nardi ${ }^{1,2,3}{ }^{(0)}$, Andrea Petroselli ${ }^{4}\left(\mathbb{D}\right.$, Ciro Apollonio ${ }^{5}(0$, \\ Ettore Arcangeletti ${ }^{5}$, Flavia Tauro ${ }^{6}{ }^{\circ}$, Claudio Belli $^{7}$, Roberto Bianconi ${ }^{7}$ and \\ Salvatore Grimaldi ${ }^{6}$
}

1 WARREDOC, Università per Stranieri di Perugia, 06123 Perugia, Italy; fernando.nardi@unistrapg.it or fnardi@fiu.edu

2 Institute of Environment, Florida International University, Miami, FL 33199, USA

3 Fondazione Eni Enrico Mattei (FEEM), 20123 Milan, Italy

4 DEIM Department, Tuscia University, 01100 Viterbo, Italy; petro@unitus.it

5 DAFNE Department, Tuscia University, 01100 Viterbo, Italy; ciro.apollonio@unitus.it (C.A.); ettore.arcangeletti@gmail.com (E.A.)

6 DIBAF Department, Tuscia University, 01100 Viterbo, Italy; flavia.tauro@unitus.it (F.T.); salvatore.grimaldi@unitus.it (S.G.)

7 TERRASYSTEM s.r.l., Tuscia University, 01100 Viterbo, Italy; c.belli@terrasystem.it (C.B.); r.bianconi@terrasystem.it (R.B.)

* Correspondence: antonio.annis@unistrapg.it

Received: 9 May 2020; Accepted: 13 June 2020; Published: 16 June 2020

\begin{abstract}
Devastating floods are observed every year globally from upstream mountainous to coastal regions. Increasing flood frequency and impacts affect both major rivers and their tributaries. Nonetheless, at the small-scale, the lack of distributed topographic and hydrologic data determines tributaries to be often missing in inundation modeling and mapping studies. Advances in Unmanned Aerial Vehicle (UAV) technologies and Digital Elevation Models (DEM)-based hydrologic modeling can address this crucial knowledge gap. UAVs provide very high resolution and accurate DEMs with low surveying cost and time, as compared to DEMs obtained by Light Detection and Ranging (LiDAR), satellite, or GPS field campaigns. In this work, we selected a LiDAR DEM as a benchmark for comparing the performances of a UAV and a nation-scale high-resolution DEM (TINITALY) in representing floodplain topography for flood simulations. The different DEMs were processed to provide inputs to a hydrologic-hydraulic modeling chain, including the DEM-based EBA4SUB (Event-Based Approach for Small and Ungauged Basins) hydrologic modeling framework for design hydrograph estimation in ungauged basins; the 2D hydraulic model FLO-2D for flood wave routing and hazard mapping. The results of this research provided quantitative analyses, demonstrating the consistent performances of the UAV-derived DEM in supporting affordable distributed flood extension and depth simulations.
\end{abstract}

Keywords: UAV-DEM; DRONE-DEM; LiDAR; TINITALY; EBA4SUB; FLO-2D; ungauged basins; flood modeling

\section{Introduction}

Remote sensing and hydrologic-hydraulic modeling data and tools, nowadays, effectively support flood hazard simulations for understanding, forecasting, and mitigating nuisance inundations in major rivers of the world. Continental models are increasingly accurate and efficient in developing flood hazard mapping [1-4] and forecasting [5,6] empowered by global meteorological and topographic surveying systems. Nonetheless, several issues impact large scale flood models, including limitations when simulating small-scale flooding dynamics [7]. For small-scale, here, we referred to the spatial 
scale, considering those small basins that have a fast response to rainfall events (in the order of 1-10 h) and that can be, thus, categorized using their time of concentration or contributing area. Longuevergne et al. 2010 [8] and Grimaldi et al. (2015) [9] defined small basins as the ones with a contributing area lower than, respectively, $250 \mathrm{~km}^{2}$ and $500 \mathrm{~km}^{2}$.

Flood modeling studies of tributaries and minor rivers are lacking behind considering their geographic (i.e., small rivers and complex and diverse landscapes) and societal scale (i.e., less people, agriculture, and industries) [10]. Those areas are, thus, challenged by inadequate financing to extend the in situ topographic data field surveys and the distribution of flow gauges and inundation studies [11-14]. The small basin knowledge gap determines increased uncertainty of flood management and mitigation strategies for many countries, both developed and developing [15-17].

Flood modeling uncertainty represents a central research topic with a significant number of studies that investigated the two major components of the inundation simulation chain: hydrology and hydraulics [18-25]. The topography is recognized to have a governing role in driving all mechanisms of surface runoff generations following extreme precipitation events and, thus, one of the most impacting factors for the accuracy of flood models [26,27]. The lack of detailed topographic datasets is still a critical factor for small-scale basins that require finer DEMs (that are often unavailable) for simulating geomorphic and hydrologic processes.

Technological advancements of Unmanned Aerial Vehicles (UAVs) provide demonstrated capabilities for effective and affordable production of optical images and topographic data surveying [28-33]. Structure from Motion (SfM) techniques allow to obtain accurate DEMs even without the use of Ground Control Points (GCPs) [34]. UAV-based topographic data are able to overcome some limitations related to traditional remotely sensed data, like the capturing of fine-scale spatial data related to hydrological processes (soil moisture, vegetation, topography, flow) in a cost-effective way and with a fine temporal resolution [35]. Besides these advantages, limited battery life-affecting maximum flight time [36], adverse wind and weather conditions [36], the quality of hardware navigation devices due to small size and the reduced payload of UAV platforms [37], requested user interaction for related commercial software [37], and UAVs flight regulations and restrictions are major constraints to their large scale uptake [38]. Moreover, limitations on data processing time, image matching in low altitude image sets, and problems of selecting accurate tie-points to reference the images in flooded areas are the main challenges for the UAV adoption during or after flood events [39]. UAV-derived topography and environmental variables and dynamics (e.g., flow depth and velocity, water-vegetation interactions) are of particular interest for small streams that are usually less investigated and have a geomorphic impulsive response to intense rainfall, causing flash floods [38]. A comprehensive review of the limitations and challenges of UAVs for environmental monitoring is provided by Manfreda et al. 2018 [31] and Yao et al. 2019 [40].

Some studies have investigated the use of UAV for environmental monitoring and modeling and specifically on flow modeling. Leitão et al. [41] performed a sensitivity analysis of the UAVs flight parameters on the accuracy of the UAV-generated DEM and obtained limited Elevation Differences (ED) with $2 \mathrm{~m}$ resolution LiDAR (mean ED equal to $0.06 \mathrm{~m}$ ). There are successful applications of UAV-derived DEM as topographic input for short rainstorm modeling [42], channel reconstruction, and flood modeling for reproducing real flood events $[43,44]$, showing some limitations mostly in highly vegetated areas (e.g., along river banks). Hashemi-Beni et al. 2018 [40] adopted UAVs for water surface detection after a flood event, providing results in agreement with the ones obtained from LiDAR DEM. Schumann et al. 2018 [38] evaluated the accuracy of a UAV-derived SfM DEM with respect to a LiDAR DEM and assessed its reliability on flood mapping by applying a simple flood-fill operation over a floodplain area. Watson et al. 2018 [45] performed a comparison of DEM accuracy analysis, landslide, and flood simulation results among a UAV-derived DEM and global DEM products (GDEM2, AW3D30, and SRTM). Sodnik et al. 2012 [46] found strong limitations on the use of public DEMs for debris flow-modeling due to their low accuracy and proposed a methodology to adopt the LiDAR-derived topography with short computational times, obtaining promising results. To our 
knowledge, procedure and assessment studies on the use of UAV-derived DEMs, with respect to large scale DEMs, for supporting the hydrologic-hydraulic modeling and flood hazard mapping chain in small basins are missing.

In this work, we proposed to fill this research gap by providing a quantitative investigation of UAVs' performances for rapid and affordable DEM data gathering and processing to support the inundation modeling of small-scale basins. A comparison of the impact of the different DEM data sources on flood mapping accuracy was developed by applying the Event-Based Approach for Small and Ungauged Basins (EBA4SUB) rainfall-runoff modeling framework [47,48] for designing hydrograph estimation and applying the commercial 2D hydraulic model FLO-2D [49] for performing the flood wave propagation simulations (Section 2). Results are presented in Section 3 with a practical case study that considered a minor tributary of a coastal basin in central Italy, analyzing the varying outcomes of the flood modeling using a freely available country scale $10 \mathrm{~m}$ DEM, a high-resolution LiDAR $1 \mathrm{~m}$ DEM, and a UAV-based DEM. A discussion and concluding remarks are discussed in Sections 4 and 5 , respectively.

\section{Data and Methods}

\subsection{Case Study}

The case study is represented by the Maschiolo torrent, a small tributary of the Marta river, in Central Italy (Figure 1). The Marta river is the emissary of the Bolsena lake and flows from the lake to the Tyrrenian sea. The Maschiolo-Marta confluence, in the proximity of Tuscania town, defines a watershed with elevation ranging from $125 \mathrm{~m}$ to $398 \mathrm{~m}$ and a total contributing area of $28.7 \mathrm{~km}^{2}$. Average elevation and slope are, respectively, $284 \mathrm{~m}$ and $7.8 \%$, while the maximum distance between outlet and watershed divide is $19.2 \mathrm{~km}$. The DEM at $10 \mathrm{~m}$ resolution was provided by the National Institute of Geophysics and Volcanology (INGV-TINITALY [50,51]), while the land cover was retrieved from CORINE Database [52], and the predominant class is non-irrigated arable land.

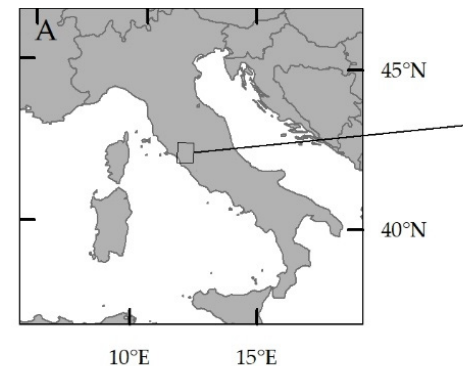

$10^{\circ} \mathrm{E} \quad 15^{\circ} \mathrm{E}$

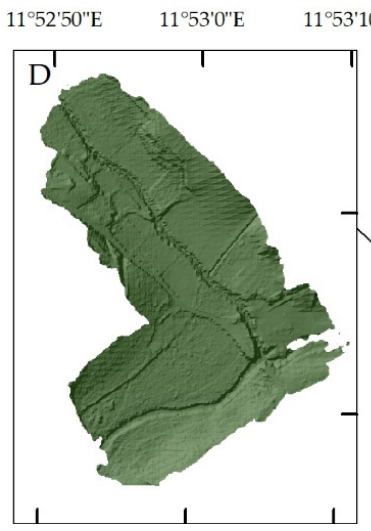

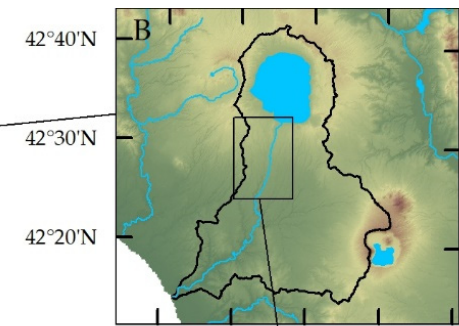

$11^{\circ} 50^{\prime} \mathrm{E} \quad 12^{\circ} \mathrm{E} \quad 12^{\circ} 10^{\prime} \mathrm{E}$

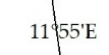

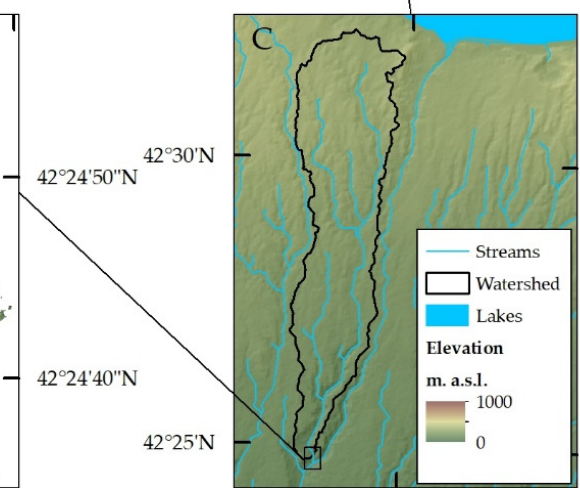

Figure 1. (A) Location of the Marta river basin in Central Italy. (B) Map of the Marta River Basin. (C) Watershed of the Maschiolo small tributary of the Marta river. (D) Map of the study area, showing the shades of the LiDAR DEM. The legend in panel C is also related to panels B and D. 


\subsection{Topography and Digital Elevation Models}

The morphology of the selected floodplain domain was obtained by gathering two digital topographic data sources from national agencies-the TINITALY and a $1 \mathrm{~m}$ LiDAR DEM provided by the Italian Ministry of Environment. The UAV flight was specifically designed and executed for supporting this research. Specifications of the three DEM products are reported in Table 1.

Table 1. Summary of specifications of the TINITALY, LiDAR, and UAV DEMs ${ }^{1}$.

\begin{tabular}{cccccc}
\hline DEM & Resolution $(\mathbf{m})$ & Coverage & Cost $\left(\mathbf{f} / \mathbf{k m}^{\mathbf{2}}\right)$ & $\begin{array}{c}\text { Vertical } \\
\text { Accuracy }(\mathbf{m})\end{array}$ & Year \\
\hline TINITALY & 10 & Entire country & Free & $\pm 16[50,51]$ & 2007 \\
LiDAR & 1 & Major rivers/coasts & $1000-5000^{1}$ & $\pm 0.15-0.30[53]$ & 2011 \\
Drone $^{3}$ & 0.25 & Local scale & $500-1500^{2}$ & \pm 0.10 & 2015 \\
\hline
\end{tabular}

${ }^{1}$ Abbreviations: Light Detection and Ranging (LiDAR); Unmanned Aerial Vehicle (UAV); Digital Elevation Models $(\mathrm{DEMs})^{2}$ The LiDAR used in this study was freely available for the coverage. In the case of on-request flight, the cost was variable as a function of the spatial domain to be surveyed with a minimum area consistent with the aerial flight plan (min. 10-100 $\mathrm{km}^{2}$ ). ${ }^{3}$ There was no minimum flight domain for Drones.

The Italian TINITALY was created from the integration of different input elevation data, including contour lines and spot heights derived from the Italian Regional topographic maps, satellite-based global positioning system points, and ground-based and radar altimetry data. The topographic data sourced were processed for producing a Triangular Irregular Network (TIN) dataset. The TIN was projected in the UTM 32 WGS 84 coordinate system and converted in a regular squared grid format with 10-m cell size and vertical accuracy of $\pm 16 \mathrm{~m}[50,51]$.

The LiDAR DEM, produced during the "Piano Straordinario di Telerilevamento ambientale" (PST) project by the Italian Ministry of Environment, was freely available in raster format in WGS84 Geographic coordinate system, divided in $0.01^{\circ}$ (angular units) cell size tiles. The surveying flights (scanning angle $25^{\circ}$, flight height $1500-1800 \mathrm{~m}$ above ground level, pulse frequency $100 \mathrm{kHz}$ ) were carried out over a period of time from 2008 to 2014 (mainly in 2011). The geometric resolution of the pixel was $0.0001^{\circ}$, corresponding to approximately $1 \mathrm{~m}$. The native resolution of the LiDAR point cloud was averaged $1.6 \mathrm{pp} / \mathrm{m}^{2}$, recording up to 4 return echoes from the single sensor output pulse [53]. Despite the good accuracy of the LiDAR DEM, some interpolation errors, like triangle patterns in the sloping areas of the north-eastern and south-western part of the domain, were evident (Figure 1D). However, these areas were outside the floodplain domain, so the LiDAR DEM could be considered acceptable for the accuracy assessment analysis.

The DEM obtained using UAV technology (i.e., Drone-DEM for brevity from now on) was generated adopting a quadcopter DJI Phantom 2 equipped with a GoPro3 + model camera, 2-axis stabilization gimbal Zenmuse H3-2D model, a ground transmission device for the live viewing of the shooting, and telemetry data sent by the autopilot control unit via iOSD device. A DJI Datalink model, autonomous as a flight programming device, was installed.

A flow chart of the steps needed to generate the Drone-DEM is represented in Figure 2. The 6 steps are hereafter described in detail. 


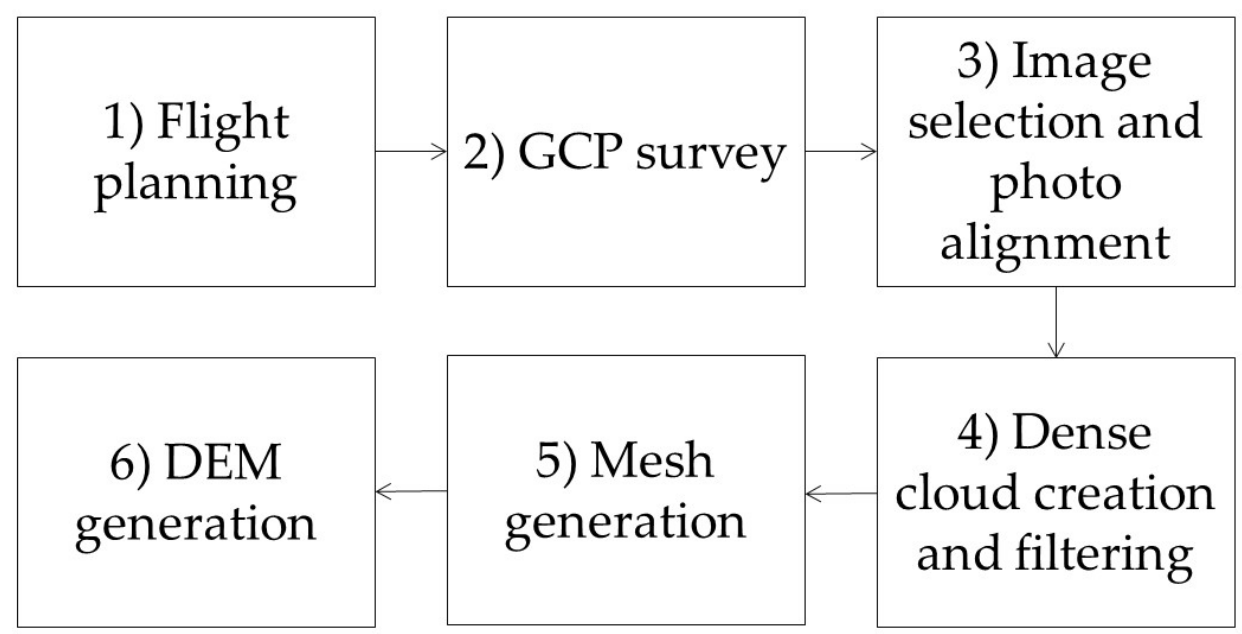

Figure 2. Flow chart of the Drone-DEM processing and production procedure. GCP, Ground Control Point.

Step (1) Flight planning (required time: around 3 man-hours). A flight plan was preliminarily investigated to identify the area of investigation. The path of the UAV was designed to cover a buffered (larger) area taking into consideration the need for maintaining a constant elevation and speed, avoiding obstacles and interdicted areas, and taking into consideration the battery-limited flight time. The predefined flight plan covered an 8 ha wide-area traveling for a $1.4 \mathrm{~km}$ distance and acquiring 1 frame every 2s. The set flight height was $100 \mathrm{~m}$ with respect to the take-off point, and the speed was $5 \mathrm{~m} / \mathrm{s}$. The camera was kept in the nadiral position throughout the flight. The nominal resolution of the photos was $2560 \times 1920$.

Step (2) GCP survey (required time: around 5 man-hours). High contrast and 11 adequately sized markers were positioned as Ground Control Points, visible in the acquired photos and, therefore, usable within the software as Ground Control Points of known coordinates (X, Y, and Z) surveyed using a GPS Leica Model.

Step (3) Data download, images selection, geopositioning, and alignment, solving internal and external orientation (required time: around 4 man-hours). The photogrammetric analysis was carried out using the Agisoft Photoscan Professional software. Once the photos were selected, the markers (i.e., GCPs) were identified, their coordinates were attributed, their six main orientation parameters were estimated, taking into account the markers and tie points automatically recognized by the software. The result of the alignment was a sparse cloud composed of the tie points.

Step (4) Dense cloud creation and filtering (required time: around 1 man-hour). After removing inaccurate points from the sparse cloud, a dense point cloud was generated starting from the sparse cloud, adding high detail to the three-dimensional model for subsequent mesh generation. To generate the DEM, a vegetation removal algorithm was applied by means of an automatic supervised process, assigning threshold values of ground slope and maximum vertical distance, while the Digital Surface Model (DSM) was generated skipping this step (Figure 3). 


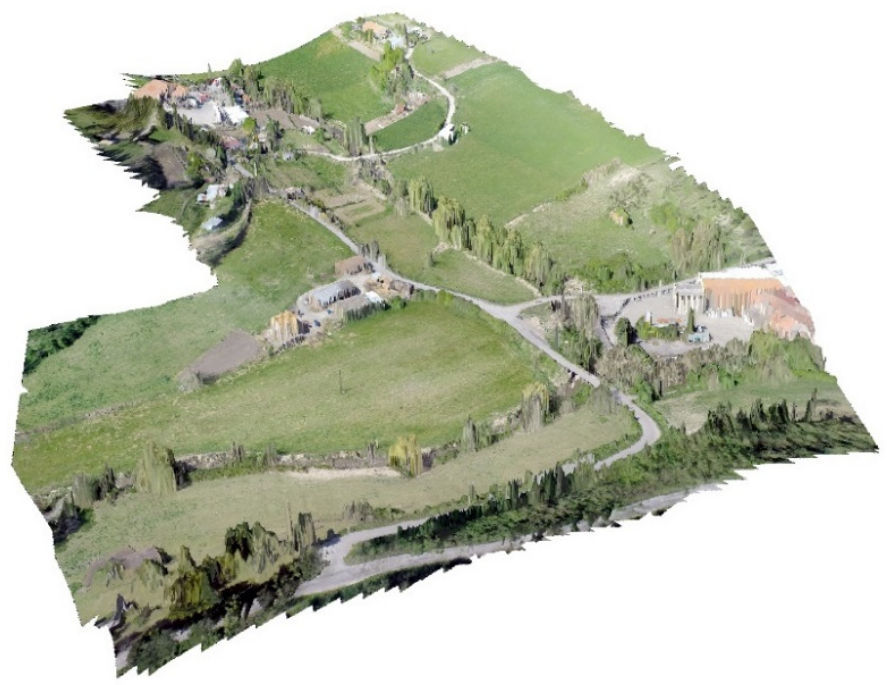

Figure 3. 3D scene of the Drone-derived Digital Surface Model (DSM) and orthophoto.

Step (5) Mesh generation (from mesh to the grid) (required time: around 0.5 man-hours). A vector mesh of the detected area was obtained, interpolating the ground points. It was noted that, in riverbed areas covered by shrubby and arboreal riparian vegetation, the reconstruction of the hidden topography was affected by some limitations.

Step (6) DEM generation (required time: around 1 man-hour). The DEM was generated, degrading the mesh and interpolating the TIN; the size of the DEM cells $(0.25 \mathrm{~m})$ was proportional to the number of points generated in the dense cloud and to the flight altitude.

A visual comparison of the three DEMs is shown in Figure 4.

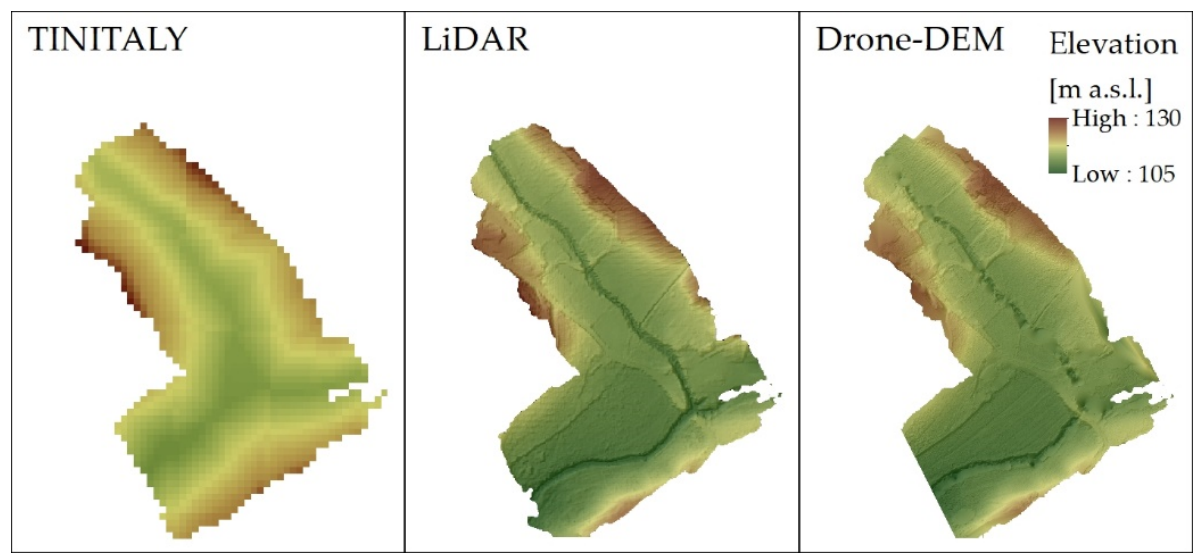

Figure 4. TINITALY, LiDAR, and Drone-DEM elevations models for the study area.

\section{DEMs Comparison}

LiDAR DEMs are usually characterized by high vertical accuracy (e.g., 0.1-0.2 m of RMSE) that is considered comparable with the sensors' noise generated by the microtopographic features [54]. For this reason, LiDAR can be considered a good benchmark for comparing the performances of flood simulations derived from other DEM sources [46].

A preliminary comparison among the three DEMs was carried out considering the LiDAR as a benchmark. Note that elevations differences among the DEMs could not be considered properly as errors, but as relative differences, because of the potential topography changes occurred during the surveying time gaps (4 years between TINITALY and LiDAR, 4 years between LiDAR and Drone-DEM). The analysis was performed, masking the computational domain inside the floodplain 
area, preliminarily determined with a hydro-geomorphic approach $[55,56]$ based on the application of power-law formulas $[57,58]$ that had been parametrized according to previous studies on basins geographically close to the study area [59]. This model has been adopted for evaluating floodplain's disconnectivity [60-62], filtering the computational domain for flood modeling [63], and DEM accuracy in floodplains [64]. Indeed, the high error value of the TINITALY $( \pm 16 \mathrm{~m})$ is expected to be lower in floodplain areas because of the absence of significant reliefs [65].

The cell-by-cell elevation comparison was performed considering the closest pixels of the TINITALY and Drone-DEM to the correspondent LiDAR. As difference metrics, the Mean Deviation (MD), Root Mean Square Deviation (RMSD), Standard Deviation (STD), and Skewness (Skew) were adopted:

$$
\begin{gathered}
\mathrm{MD}=\frac{\sum_{\mathrm{i}=1}^{\mathrm{n}}\left(\Delta \mathrm{h}_{\mathrm{i}}\right)}{\mathrm{n}} \\
\mathrm{RMSD}=\sqrt{\frac{\sum_{\mathrm{i}=1}^{\mathrm{n}} \Delta \mathrm{h}_{\mathrm{i}}{ }^{2}}{\mathrm{n}}} \\
\mathrm{STD}=\sqrt{\frac{\sum_{\mathrm{i}=1}^{\mathrm{n}}\left(\Delta \mathrm{h}_{\mathrm{i}}-\mathrm{MD}\right)^{2}}{\mathrm{n}-1}} \\
\text { Skew }=\frac{\frac{\sum_{\mathrm{i}=1}^{\mathrm{n}}\left(\Delta \mathrm{h}_{\mathrm{i}}-\mathrm{MD}\right)^{3}}{\mathrm{n}}}{\left(\frac{\sum_{\mathrm{i}=1}^{\mathrm{n}}\left(\Delta \mathrm{h}_{\mathrm{i}}-\mathrm{MD}\right)^{2}}{\mathrm{n}}\right)^{\frac{3}{2}}}
\end{gathered}
$$

where $\Delta \mathrm{h}_{\mathrm{i}}$ is the elevation difference between the reference LiDAR and the analyzed DEM of the $i$-pixel, and $\mathrm{n}$ is the total number of pixels.

\subsection{Hydrologic Modeling}

The design flood wave hydrograph for the case study was estimated, employing the EBA4SUB (Event-Based Approach for Small and Ungauged Basins) [66] procedure. EBA4SUB estimated the design hydrograph, implementing the following steps: (a) event-based analysis of design hyetograph; (b) excess rainfall estimation; (c) excess rainfall-runoff modeling.

Step (a) was implemented by gathering the Intensity-Duration-Frequency (IDF) curves from the VAlutazione delle Piene in Italia (VAPI) method [67] for the return periods of 10, 50, 100, and 200 years. For this case study, the symmetric Chicago method was adopted as a design hyetograph. Starting from the gross rainfall, the excess rainfall was estimated by applying the mixed procedure CN4GA [68,69], where Curve Number $(\mathrm{CN})$ value was assessed using the Natural Resources Conservation Service (NRCS) tables [70]. Land cover data and Hydrologic Soil Groups (HSG) were provided, respectively, from the Istituto Superiore per la Protezione e la Ricerca Ambientale (ISPRA) and the Regione Lazio.

Step (b) was implemented by applying DEM-based terrain analysis processing (i.e., removal of pits and flat areas; flow directions, flow accumulation, and drainage network identification) for supporting the application of the Width Function Instantaneous Unit Hydrograph (WFIUH) rainfall-runoff model $[48,71]$. The WFIUH simulated the geomorphic response of the river basin to the rainfall input by analyzing the travel-time probability density function for defining the Instantaneous Unit Hydrograph (IUH). Parametrization of the WFIUH was developed by assuming hillslope's surface flow velocities so that its center of mass was equal to the basin's lag time $[9,47]$.

\subsection{Hydraulic Modeling}

The design hydrograph was inserted as a boundary condition and routed using the FLO-2D bidimensional (2D) hydraulic model [49]. FLO-2D applied the dynamic wave approximation to the De Saint Venant continuity and momentum equations for simulating channel routing (1D), river overbank inundation flow, river-floodplain flow exchange, and runoff routing over unconfined flow (2D) 
dynamics. The floodplain morphology was represented with regularly spaced squares (i.e., regular grid, raster) with 8 potential surface flow directions ( 4 cardinal and 4 diagonal directions). The differential form of the model equations was solved with a central, finite difference numerical scheme. Surface flow friction losses were estimated integrating Manning's roughness depth-varying parameterization. Interaction of surface runoff with urban features (e.g., levees, bridges, culverts, buildings) was simulated, adopting areal reduction factors and simplified conveyance routines employing rating curves or simplified models for considering breaching and overtopping mechanisms.

The computational domain was 12 ha wide, and the upstream channel element was around $500 \mathrm{~m}$ far from the confluence with the Marta river. The $10 \mathrm{~m}$ grid resolution was selected as optimal shared (i.e., across the different model set-ups) working scale to compare the results of the simulations considering the three different DEM specifications. Manning values ranged from 0.04 to $0.06 \mathrm{~m} / \mathrm{s}^{1 / 3}$, assigned, respectively, to lower and higher vegetation densities as per visual inspection of the Drone-derived orthophotos. The available CORINE land cover resolution (100 $\mathrm{m})$ was not adequate to assign Manning values. At the $10 \mathrm{~m}$ scale, a constant Manning value equal to $0.04 \mathrm{~m} / \mathrm{s}^{1 / 3} \mathrm{was}$ assigned to the channel domain. These values were consistent with the ones obtained from literature related to the calibration of the hydraulic model of the Marta river (Annis et al. 2020 [72]).

The channel geometry was derived, extracting 27 cross-sections from the LiDAR DEM. We designed the comparison experiment of the three flood models, neglecting the impact of the channel geometry differences considering that DEM-based representation of the bathymetry is always poor (in TINITALY as well as in the Lidar and the UAV DEM). For this reason, the same LiDAR-derived channel geometry was assigned to the Drone-DEM and TINITALY computational domains in order to consistently compare the model results focusing on the floodplain domain.

\subsection{Inundation Extent Performance Indicators}

A numerical comparison of the maximum asynchronous flood extensions (i.e., the envelope of maximum flow extensions over simulation time) related to the different input DEMs was performed, adopting the three different scores, namely, the True Positive rate (TP), the False Positive rate (FP), and the Critical Success Index (CSI):

$$
\begin{gathered}
\mathrm{TP}=\frac{\mathrm{A}}{\mathrm{A}+\mathrm{C}} \\
\mathrm{FP}=\frac{\mathrm{B}}{\mathrm{A}+\mathrm{B}} \\
\mathrm{CSI}=\frac{\mathrm{A}}{\mathrm{A}+\mathrm{B}+\mathrm{C}}
\end{gathered}
$$

where A, B, and C represent, respectively, the matched, over-predicted, and under-predicted areas with respect to the reference flood map (from the LiDAR).

Moreover, the differences of flow depth were computed adopting MD, RMSD, and STD metrics introduced in Section 2.2, where, in this case, $\Delta h_{i}$ is the water depth difference between the reference LiDAR-derived flood map and the one derived from the analyzed DEM of the $i$-pixel.

\section{Results}

\subsection{DEMs Comparison}

From a visual inspection of Figure 4, the Drone-DEM seemed more accurate than the TINITALY with respect to the LiDAR DEM. This was confirmed by the statistical measurements shown in Table 2 and by the distribution of the elevation differences of Drone-DEM and TINITALY with respect to LiDAR shown in Figure 5. Specifically, Table 2 shows a relevant negative MD of the TINITALY with respect to the LiDAR. This meant that the systematic error of TINITALY, expressed by the Mean Deviation, could cause an underestimation of the flooded areas adopting this DEM as topographic input of a flood inundation model. A slight negative MD value for the Drone-DEM could be due to the presence of the short height floodplain vegetation [73] that has not been properly removed by the adopted vegetation removal algorithm. RMSD and STD values showed a significant correspondence between the LiDAR and the Drone-DEM with respect to the TINITALY. The negative skewness $(-4.44)$ 
of the Drone-DEM could be due to the mentioned presence of the short vegetation, while the TINITALY elevation error distribution seemed to be more symmetrical with respect to the biased MD value of $-5.76 \mathrm{~m}$.

Table 2. Difference metrics of the TINITALY and Drone-DEM with respect to the LiDAR ${ }^{1}$.

\begin{tabular}{ccccc}
\hline DEM & MD $(\mathbf{m})$ & RMSD $(\mathbf{m})$ & STD $(\mathbf{m})$ & Skew $(-)$ \\
\hline TINITALY & -5.76 & 6.10 & 2.01 & -0.89 \\
Drone-DEM & -0.05 & 0.75 & 0.75 & -4.44 \\
\hline
\end{tabular}

1 Abbreviations: Mean Deviation (MD), Root Mean Square Deviation (RMSD), Standard Deviation (STD), Skewness (Skew).

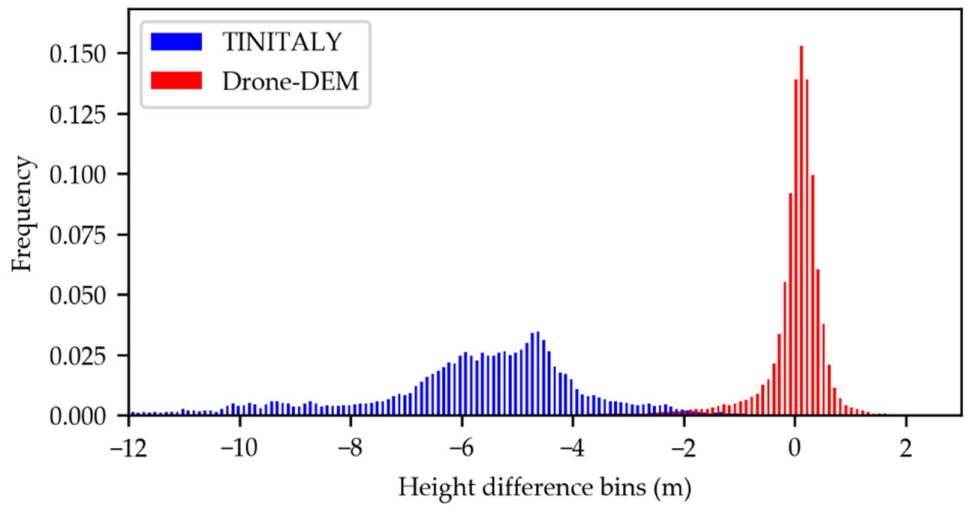

Figure 5. Distributions of the height differences of the TINITALY and Drone-DEM with respect to the LiDAR.

\subsection{Inundation Modeling and Mapping Comparison}

In Figure 6, the gross hyetographs, the excess rainfall hyetographs, and the direct runoff hydrographs are shown for the selected return periods.
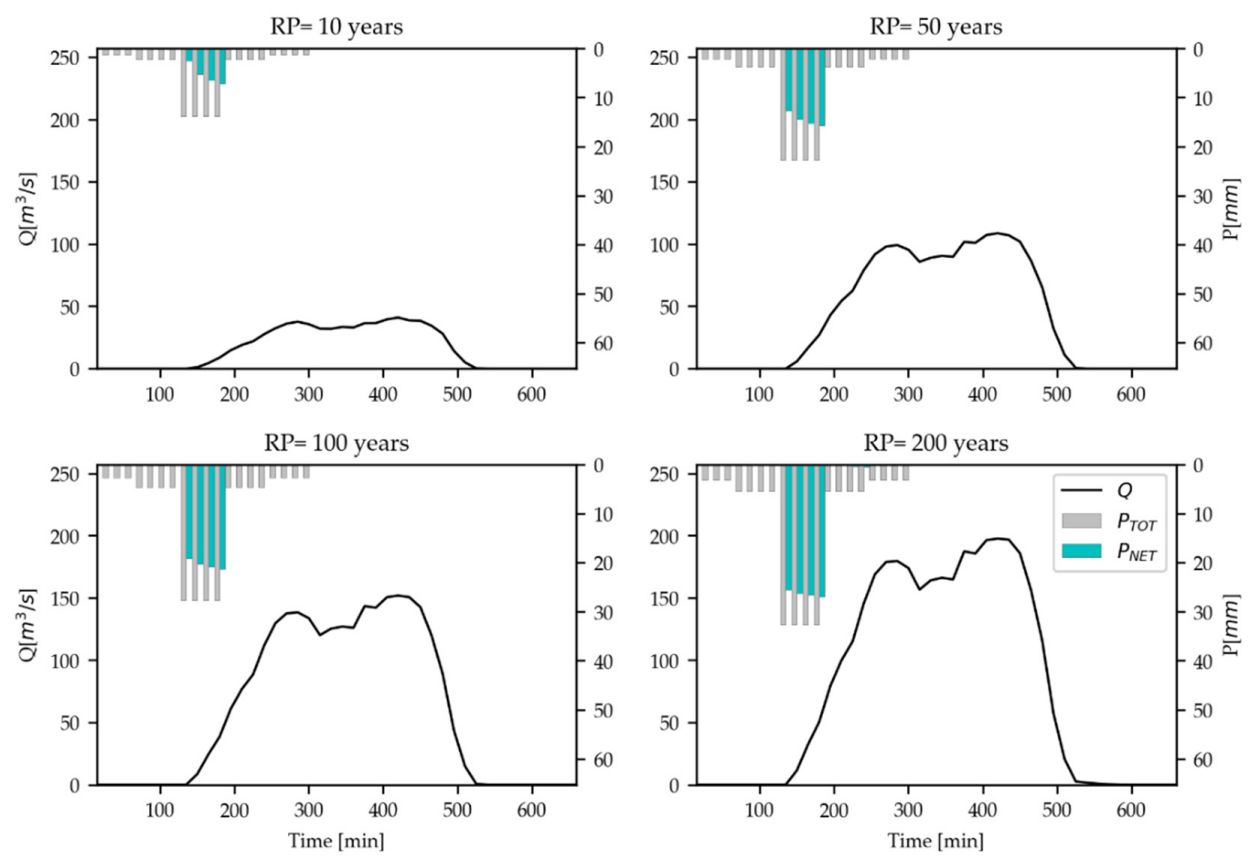

Figure 6. Gross Chicago hyetographs $\left(P_{T O T}\right)$ and excess rainfall hyetographs $\left(P_{N E T}\right)$ (upper x-axis), and design hydrograph (Q-lower x-axis) for the selected return times (10, 50, 100, and 200 years). 
Results on the relative extensions of the flood maps derived from the TINITALY and Drone-DEM with respect to the LiDAR are reported in Table 3. For each selected return period, the TP values related to the Drone-DEM flood maps were between 0.96 and 0.98 . This meant that the Drone-DEM had a high probability to effectively identify the flooded area as compared to the LiDAR-based reference flood model. Both Drone-DEM and TINITALY flood maps were characterized by a high False Positive rate for the 10 years return period simulation. As clearly shown in the TD.10 panel of Figure 7, this was due to the fact that, for relatively low flows, the Drone-DEM and TINITALY allowed an inundation flow over the right bank due to lower terrain elevations with respect to the LiDAR. Since flood areas for the 10 years return period simulations were relatively low, the high value of FP caused relatively low values of the CSI. For each simulation, the Drone-DEM flood maps were characterized by better performances with respect to the ones from TINITALY. The latter seemed to strongly under-predict the areas located in the downstream part of the computational domain. This was due to the substantial negative value of the MD, as shown in Table 2. The inaccuracy of the results obtained adopting the TINITALY DEM was consistent with the ones obtained by Sodnik et al. 2012 [46] adopting public DEMs. This outcome could help the flood modelers to understand the limitation of using largely and freely available DEMs, usually affected by systematic errors, in small basins characterized by relatively narrow floodplain that would require detailed topography.

Table 3. Scores of the spatial comparison between the maximum asynchronous flood extension of the LiDAR-derived computational domain (reference map) and the ones derived from TINITALY and Drone-DEM ${ }^{1}$.

\begin{tabular}{ccccc}
\hline Return Period (Years) & DEM & TP & FP & CSI \\
\hline \multirow{2}{*}{10} & TINITALY & 0.57 & 0.66 & 0.27 \\
& Drone-DEM & 0.96 & 0.67 & 0.32 \\
\multirow{2}{*}{50} & TINITALY & 0.70 & 0.16 & 0.62 \\
& Drone-DEM & 1.00 & 0.21 & 0.79 \\
\multirow{2}{*}{200} & TINITALY & 0.71 & 0.09 & 0.66 \\
& Drone-DEM & 0.98 & 0.13 & 0.86 \\
& TINITALY & 0.72 & 0.03 & 0.71 \\
& Drone-DEM & 0.98 & 0.07 & 0.92 \\
\hline
\end{tabular}

$1 \overline{\text { Abbreviations: True Positive rate (TP), False Positive rate (FP), Critical Success Index (CSI). }}$

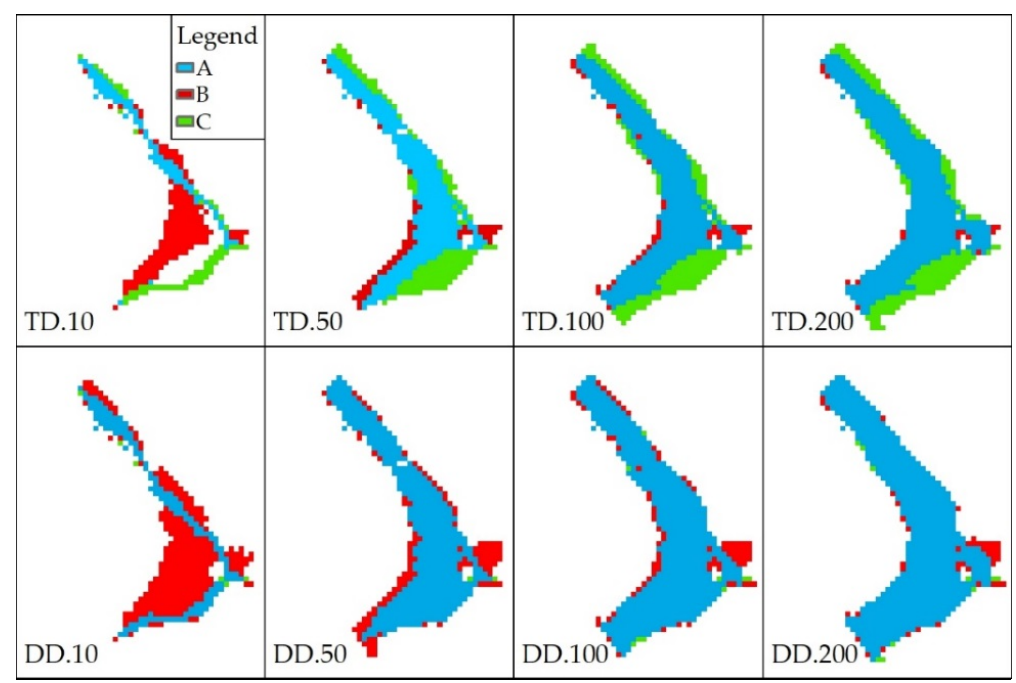

Figure 7. Maps of matching: A, overpredicted: B, and underpredicted: C; areas of simulations from TINITALY (TD-upper panels) and Drone-DEM (DD-lower panels) for the selected return periods-10, 50,100 , and 200 years (left to right panels). 
Figures 8 and 9 show that LiDAR and Drone-DEM flood maps were more consistent in terms of distributions of the maximum asynchronous flow depths and flow velocities for the 200 years return period with respect to the TINITALY flood maps. However, Drone-DEM flood maps had higher values of flow depths and velocities in the downstream part of the right river bank; this was due to a relatively lower depression of the terrain that caused significant differences in flood extensions for low magnitude flood simulations (see Table 3 and Figure 7). Values of MD, RMSD, and STD of the maximum flow depths distributions of the TINITALY and Drone-DEM flood maps with respect to the LiDAR ones for each return period are reported in Table 4.

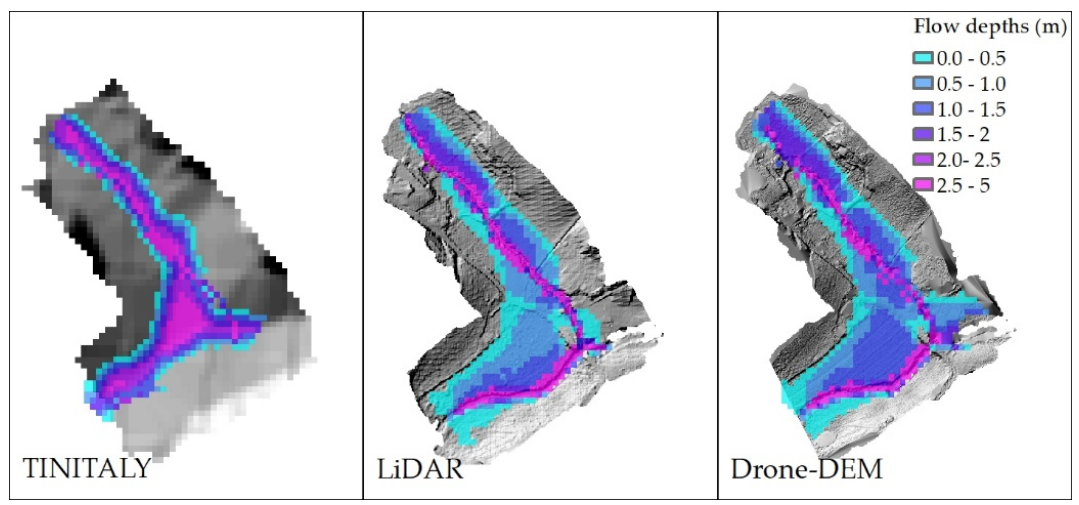

Figure 8. Maximum asynchronous flow depths of the simulations from TINITALY, LiDAR, and Drone-DEM (200 years return period).

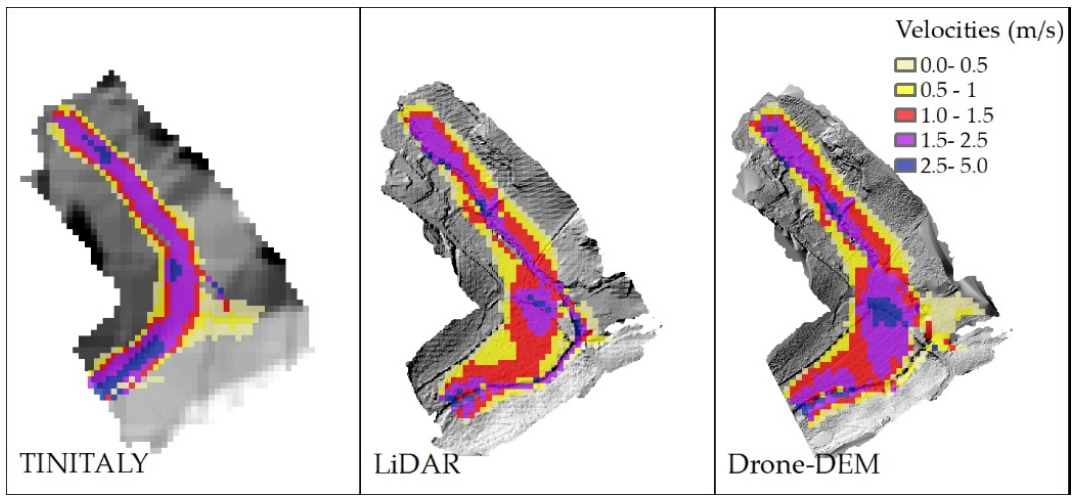

Figure 9. Maximum asynchronous flow velocities of the simulations from TINITALY, LiDAR, and Drone-derived DEMs (200 years return period).

Table 4. Values of Mean Deviation (MD), Root Mean Square Deviation (RMSD), Standard Deviation (STD) of the maximum flow depths distributions of the simulations related to the TINITALY and Drone-DEM computational domains with respect to the ones of LiDAR-derived computational domain for the selected return periods $(10,50,100,200$ years).

\begin{tabular}{ccccc}
\hline Return Period (Years) & DEM & MD & RMSD & STD \\
\hline \multirow{2}{*}{10} & TINITALY & 0.01 & 0.42 & 0.42 \\
& Drone-DEM & -0.13 & 0.56 & 0.55 \\
\multirow{2}{*}{50} & TINITALY & -0.49 & 1.11 & 1.00 \\
& Drone-DEM & -0.11 & 0.49 & 0.48 \\
\multirow{2}{*}{100} & TINITALY & -0.45 & 1.13 & 1.04 \\
& Drone-DEM & -0.04 & 0.46 & 0.46 \\
\multirow{2}{*}{200} & TINITALY & -0.42 & 1.14 & 1.06 \\
& Drone-DEM & -0.02 & 0.46 & 0.46 \\
\hline
\end{tabular}


Values of MD for Drone-DEM flood maps were considerably lower, if compared with the ones of the TINITALY flood maps, with the exception of the values related to the 10 years return period simulation, because of the significant differences in flood extensions (higher flood extension for the same flood volume led to lower flow depths, thus negative Mean Deviations). Values of RMSD and STD for the Drone-DEM flood maps were generally more than $50 \%$ lower than the ones of the TINITALY flood maps, with the exception of the 10 years return period simulation for the same reason explained above.

\section{Discussion}

The proposed research emphasized the potential benefits of low-cost UAVs-derived DEM with respect to freely available large scale DEM for flood mapping in small-scale basins.

Advances in UAVs-derived DEMs, such as Structure from Motion (SfM) techniques [34], allow reducing the surveying costs and times while covering scarcely accessible areas. Rapid UAV mapping can also meet the need of providing updated topography, whose changes due to human activities [74] or erosion-deposition processes [75] can strongly influence flood dynamics. Moreover, the relatively low flight height and high accuracy of UAVs-derived DEMs can be particularly effective in peri-urban environments where anthropic features (e.g., thin walls), which have a crucial impact on flood dynamics, cannot be properly detected by satellite or airborne imaging survey technologies. In fact, anthropogenic and vegetation features in floodplain areas represent a major challenge for airborne or satellite products, considering most inundation models require bare earth DEM and artificial features as two separate inputs [22,76-78]. Indeed, while minor infrastructure and micro-topographic features are usually only explicitly defined in flood model parametrization [79,80], they may have a great influence on flow dynamics [54] as in the case of man-made flow constrictions (streets, gutters, swales), obstacles or diverters (boundary walls, buildings), obstructions (e.g., culverts, ridges), and flow regulators (weirs, detention ponds) [81].

The approach adopted in this work could provide quick and accurate support to decision-makers for the identification of hazard areas, in order to define measures intended at reducing the flood risk and for the implementation of flooding protection policies. A further improvement of this research could be addressed to exploit faster Drone-derived DEM generation techniques (e.g., the SfM) to include different case studies and types of large scale available DEMs in order to systematically quantify the simulations performances, varying floodplain morphology, and climate.

\section{Conclusions}

In this work, we investigated the potential benefits of UAV-derived DEMs with respect to a freely and largely available DEM (TINITALY) for flood modeling in small basins. We considered as a benchmark a validated high-resolution LiDAR DEM $(1 \mathrm{~m})$ characterized by a vertical accuracy $(0.15-0.3 \mathrm{~m})$. Drone-DEM flood simulations performed significantly better than the ones derived from the TINITALY DEM in terms of metrics related to flood extensions and maximum asynchronous flow depths. These differences were not negligible (e.g., $72 \%$ of flood extension matching from TINITALY flood maps versus $98 \%$ from Drone-DEM flood maps for the 200 years return period simulation) and suggested that flow dynamics could be substantially influenced by detailed topographic features at the local scale in small basins characterized by limited flood volumes and floodplain width. The obtained results supported the conclusion that the UAV-derived DEMs could be an appropriate alternative to the LiDAR DEM for small basin flood mapping being a good compromise between accuracy and cost compared to the freely available DEM (TINITALY).

Author Contributions: Conceptualization, S.G. and F.N.; data gathering, A.A. and A.P.; Drone flight and data processing, C.B., R.B., E.A., F.T. and A.A.; EBA4SUB modeling, A.P. and C.A.; FLO-2D modeling, A.A.; writing—original draft preparation, A.A., S.G., and F.N.; figures and tables, A.A.; writing-review and editing of the final document by all authors; funding acquisition, S.G. and F.N. All authors have read and agreed to the published version of the manuscript. 
Funding: This research received funding by: the Italian Ministry of the Environment, Land and Sea (MATTM) through the projects "GEST-RIVER Gestione ecosostenibile dei territori a rischio inondazione e valorizzazione economica delle risorse" and "SIMPRO SIMulazione idrologico-idraulico-economica di PROgetto per la mitigazione del rischio idraulico"; the University for Foreigners of Perugia-Regione Lazio Grant Research Agreement No. A11598 (Research grant "PS1 Tiber river Orte-Castel Giubileo Flood Risk Master Plan, Media Valle del fiume Tevere").

Acknowledgments: F.N. and A.A. acknowledge the support received by the WARREDOC center of University for Foreigners of Perugia through the WARREDOC-Fondazione ENI Enrico Mattei (FEEM) research agreement. F.N. acknowledges the support received by the Southeast Environmental Research Center in the Institute of Environment at Florida International University.

Conflicts of Interest: The authors declare no conflict of interest.

\section{References}

1. Sampson, C.C.; Smith, A.M.; Bates, P.B.; Neal, J.C.; Alfieri, L.; Freer, J.E. A High-Resolution Global Flood Hazard Model. Water Resour. Res. 2015. [CrossRef] [PubMed]

2. Dottori, F.; Salamon, P.; Bianchi, A.; Alfieri, L.; Hirpa, F.A.; Feyen, L. Development and Evaluation of a Framework for Global Flood Hazard Mapping. Adv. Water Resour. 2016, 94, 87-102. [CrossRef]

3. Alfieri, L.; Bisselink, B.; Dottori, F.; Naumann, G.; Wyser, K.; Feyen, L.; De Roo, A. Global Projections of River Flood Risk in a Warmer World. Earth's Future 2017. [CrossRef]

4. Wing, O.E.J.; Bates, P.D.; Sampson, C.C.; Smith, A.M.; Johnson, K.A.; Erickson, T.A. Validation of a $30 \mathrm{~m}$ Resolution Flood Hazard Model of the Conterminous United States. Water Resour. Res. 2017, 53, 7968-7986. [CrossRef]

5. Alfieri, L.; Burek, P.; Dutra, E.; Krzeminski, B.; Muraro, D.; Thielen, J.; Pappenberger, F. GloFAS-Global Ensemble Streamflow Forecasting and Flood Early Warning. Hydrol. Earth Syst. Sci. 2013. [CrossRef]

6. Wu, H.; Adler, R.F.; Tian, Y.; Huffman, G.J.; Li, H.; Wang, J. Real-Time Global Flood Estimation Using Satellite-Based Precipitation and a Coupled Land Surface and Routing Model. Water Resour. Res. 2014. [CrossRef]

7. Ward, P.J.; Jongman, B.; Salamon, P.; Simpson, A.; Bates, P.; De Groeve, T.; Muis, S.; De Perez, E.C.; Rudari, R.; Trigg, M.A.; et al. Usefulness and Limitations of Global Flood Risk Models. Nat. Clim. Chang. 2015. [CrossRef]

8. $\quad$ Longuevergne, L.; Scanlon, B.R.; Wilson, C.R. GRACE Hydrological Estimates for Small Basins: Evaluating Processing Approaches on the High Plains Aquifer, USA. Water Resour. Res. 2010. [CrossRef]

9. Grimaldi, S.; Petroselli, A. Do We Still Need the Rational Formula? An Alternative Empirical Procedure for Peak Discharge Estimation in Small and Ungauged Basins. Hydrol. Sci. J. 2015, 60, 67-77. [CrossRef]

10. Blöschl, G.; Sivapalan, M.; Wagener, T.; Viglione, A.; Savenije, H. Runoff Prediction in Ungauged Basins: Synthesis across Processes, Places and Scales; Cambridge University Press: Cambridge, UK, 2013. [CrossRef]

11. Ignacio, J.A.F.; Cruz, G.T.; Nardi, F.; Henry, S. Assessing the Effectiveness of a Social Vulnerability Index in Predicting Heterogeneity in the Impacts of Natural Hazards: Case Study of the Tropical Storm Washi Flood in the Philippines. Vienna Yearb. Popul. Res. 2015. [CrossRef]

12. Convertino, M.; Annis, A.; Nardi, F. Information-Theoretic Portfolio Decision Model for Optimal Flood Management. Environ. Model. Softw. 2019, 119, 258-274. [CrossRef]

13. McCabe, M.F.; Rodell, M.; Alsdorf, D.E.; Miralles, D.G.; Uijlenhoet, R.; Wagner, W.; Lucieer, A.; Houborg, R.; Verhoest, N.E.C.; Franz, T.E.; et al. The Future of Earth Observation in Hydrology. Hydrol. Earth Syst. Sci. 2017. [CrossRef] [PubMed]

14. Tauro, F.; Selker, J.; Van De Giesen, N.; Abrate, T.; Uijlenhoet, R.; Porfiri, M.; Manfreda, S.; Caylor, K.; Moramarco, T.; Benveniste, J.; et al. Measurements and Observations in the XXI Century (MOXXI): Innovation and Multi-Disciplinarity to Sense the Hydrological Cycle. Hydrol. Sci. J. 2018. [CrossRef]

15. Merwade, V.; Olivera, F.; Arabi, M.; Edleman, S. Uncertainty in Flood Inundation Mapping: Current Issues and Future Directions. J. Hydrol. Eng. 2008. [CrossRef]

16. Grimaldi, S.; Petroselli, A.; Arcangeletti, E.; Nardi, F. Flood Mapping in Ungauged Basins Using Fully Continuous Hydrologic-Hydraulic Modeling. J. Hydrol. 2013. [CrossRef]

17. Figorito, B.; Tarantino, E.; Balacco, G.; Fratino, U. An Object-Based Method for Mapping Ephemeral River Areas from WorldView-2 Satellite Data. In Remote Sensing for Agriculture, Ecosystems, and Hydrology XIV; SPIE: Bellingham, WA, USA, 2012. [CrossRef] 
18. Pappenberger, F.; Matgen, P.; Beven, K.J.; Henry, J.B.; Pfister, L.; Fraipont, P. Influence of Uncertain Boundary Conditions and Model Structure on Flood Inundation Predictions. Adv. Water Resour. 2006. [CrossRef]

19. Apel, H.; Merz, B.; Thieken, A.H. Quantification of Uncertainties in Flood Risk Assessments. Int. J. River Basin Manag. 2008. [CrossRef]

20. Bhuyian, M.N.M.; Kalyanapu, A.J.; Nardi, F. Approach to Digital Elevation Model Correction by Improving Channel Conveyance. J. Hydrol. Eng. 2015. [CrossRef]

21. De Paola, F.; Giugni, M.; Pugliese, F.; Annis, A.; Nardi, F. GEV Parameter Estimation and Stationary vs. Non-Stationary Analysis of Extreme Rainfall in African Test Cities. Hydrology 2018, 5. [CrossRef]

22. Nardi, F.; Annis, A.; Biscarini, C. On the Impact of Urbanization on Flood Hydrology of Small Ungauged Basins: The Case Study of the Tiber River Tributary Network within the City of Rome. J. Flood Risk Manag. 2018, 11, S594-S603. [CrossRef]

23. Liu, Z.; Merwade, V.; Jafarzadegan, K. Investigating the Role of Model Structure and Surface Roughness in Generating Flood Inundation Extents Using One- and Two-Dimensional Hydraulic Models. J. Flood Risk Manag. 2019. [CrossRef]

24. Petroselli, A.; Vojtek, M.; Vojteková, J. Flood Mapping in Small Ungauged Basins: A Comparison of Different Approaches for Two Case Studies in Slovakia. Hydrol. Res. 2019. [CrossRef]

25. Peña, F.; Nardi, F. Floodplain Terrain Analysis for Coarse Resolution 2D Flood Modeling. Hydrology 2018. [CrossRef]

26. Yan, K.; Di Baldassarre, G.; Solomatine, D.P.; Schumann, G.J.P. A Review of Low-Cost Space-Borne Data for Flood Modelling: Topography, Flood Extent and Water Level. Hydrol. Process. 2015. [CrossRef]

27. Gioia, A.; Totaro, V.; Bonelli, R.; Esposito, A.A.M.G.; Balacco, G.; Iacobellis, V. Flood Susceptibility Evaluation on Ephemeral Streams of Southern Italy: A Case Study of Lama Balice. In Lecture Notes in Computer Science (including Subseries Lecture Notes in Artificial Intelligence and Lecture Notes in Bioinformatics); Springer: Cham, Switzerland, 2018. [CrossRef]

28. Sammartano, G.; Spanò, A. DEM Generation Based on UAV Photogrammetry Data in Critical Areas. In Proceedings of the 2nd International Conference on Geographical Information Systems Theory, Applications and Management, Rome, Italy, 26-27 April 2016; pp. 92-98. [CrossRef]

29. Polat, N.; Uysal, M. DTM Generation with UAV Based Photogrammetric Point Cloud. Int. Arch. Photogramm. Remote Sens. Spat. Inf. Sci.-ISPRS Arch. 2017, 42, 77-79. [CrossRef]

30. Arif, F.; Abdul Maulud, K.N.; Ab Rahman, A.A. Generation of Digital Elevation Model through Aerial Technique. IOP Conf. Ser. Earth Environ. Sci. 2018, 169. [CrossRef]

31. Manfreda, S.; McCabe, M.F.; Miller, P.E.; Lucas, R.; Madrigal, V.P.; Mallinis, G.; Dor, E.B.; Helman, D.; Estes, L.; Ciraolo, G.; et al. On the Use of Unmanned Aerial Systems for Environmental Monitoring. Remote Sens. 2018, 10. [CrossRef]

32. Aguilar, F.J.; Rivas, J.R.; Nemmaoui, A.; Peñalver, A.; Aguilar, M.A. UAV-Based Digital Terrain Model Generation under Leaf-off Conditions to Support Teak Plantations Inventories in Tropical Dry Forests. A Case of the Coastal Region of Ecuador. Sensors (Switzerland) 2019, 19, 1934. [CrossRef]

33. Pellicani, R.; Argentiero, I.; Manzari, P.; Spilotro, G.; Marzo, C.; Ermini, R.; Apollonio, C. UAV and Airborne LiDAR Data for Interpreting Kinematic Evolution of Landslide Movements: The Case Study of the Montescaglioso Landslide (Southern Italy). Geosciences 2019. [CrossRef]

34. Fonstad, M.A.; Dietrich, J.T.; Courville, B.C.; Jensen, J.L.; Carbonneau, P.E. Topographic Structure from Motion: A New Development in Photogrammetric Measurement. Earth Surf. Process. Landf. 2013. [CrossRef]

35. DeBell, L.; Anderson, K.; Brazier, R.E.; King, N.; Jones, L. Water Resource Management at Catchment Scales Using Lightweight UAVs: Current Capabilities and Future Perspectives. J. Unmanned Veh. Syst. 2016, 4, 7-30. [CrossRef]

36. Kim, S.J.; Lim, G.J.; Cho, J. Drone Flight Scheduling under Uncertainty on Battery Duration and Air Temperature. Comput. Ind. Eng. 2018. [CrossRef]

37. Nex, F.; Remondino, F. UAV for 3D Mapping Applications: A Review. Appl. Geomat. 2014. [CrossRef]

38. Schumann, G.J.P.; Muhlhausen, J.; Andreadis, K.M. Rapid Mapping of Small-Scale River-Floodplain Environments Using UAV SfM Supports Classical Theory. Remote Sens. 2019, 11, 982. [CrossRef]

39. Hashemi-Beni, L.; Jones, J.; Thompson, G.; Johnson, C.; Gebrehiwot, A. Challenges and Opportunities for UAV-Based Digital Elevation Model Generation for Flood-Risk Management: A Case of Princeville, North Carolina. Sensors 2018, 18, 3843. [CrossRef] 
40. Yao, H.; Qin, R.; Chen, X. Unmanned Aerial Vehicle for Remote Sensing Applications-A Review. Remote Sens. 2019. [CrossRef]

41. Leitão, J.P.; Moy De Vitry, M.; Scheidegger, A.; Rieckermann, J. Assessing the Quality of Digital Elevation Models Obtained from Mini Unmanned Aerial Vehicles for Overland Flow Modelling in Urban Areas. Hydrol. Earth Syst. Sci. 2016, 20, 1637-1653. [CrossRef]

42. Backes, D.; Schumann, G.; Teferele, F.N.; Boehm, J. Towards a High-Resolution Drone-Based 3D Mapping Dataset to Optimise Flood Hazard Modelling. Int. Arch. Photogramm. Remote Sens. Spat. Inf. Sci.-ISPRS Arch. 2019, 42, 181-187. [CrossRef]

43. Mourato, S.; Fernandez, P.; Pereira, L.; Moreira, M. Improving a DSM Obtained by Unmanned Aerial Vehicles for Flood Modelling. IOP Conf. Ser. Earth Environ. Sci. 2017, 95. [CrossRef]

44. Langhammer, J.; Bernsteinová, J.; Miřijovský, J. Building a High-Precision 2D Hydrodynamic Flood Model Using UAV Photogrammetry and Sensor Network Monitoring. Water 2017, 9, 861. [CrossRef]

45. Watson, C.; Kargel, J.; Tiruwa, B. UAV-Derived Himalayan Topography: Hazard Assessments and Comparison with Global DEM Products. Drones 2019, 3, 18. [CrossRef]

46. Sodnik, J.; Vrečko, A.; Podobnikar, T.; Mikoš, M. Digital Terrain Models and Mathematical Modelling of Debris Flows. Geod. Vestn. 2012. [CrossRef]

47. Petroselli, A.; Grimaldi, S. Design Hydrograph Estimation in Small and Fully Ungauged Basins: A Preliminary Assessment of the EBA4SUB Framework. J. Flood Risk Manag. 2018, 11, S197-S210. [CrossRef]

48. Grimaldi, S.; Petroselli, A.; Nardi, F. A Parsimonious Geomorphological Unit Hydrograph for Rainfall-Runoff Modelling in Small Ungauged Basins. Hydrol. Sci. J. 2012. [CrossRef]

49. O’Brien, J.S.; Julien, P.Y.; Fullerton, W.T. Two-Dimensional Water Flood and Mudflow Simulation. J. Hydraul. Eng. 1993. [CrossRef]

50. Tarquini, S.; Isola, I.; Favalli, M.; Mazzarini, F.; Bisson, M.; Pareschi, M.T.; Boschi, E. TINITALY/01: A New Triangular Irregular Network of Italy. Ann. Geophys. 2007. [CrossRef]

51. Tarquini, S.; Vinci, S.; Favalli, M.; Doumaz, F.; Fornaciai, A.; Nannipieri, L. Release of a 10-m-Resolution DEM for the Italian Territory: Comparison with Global-Coverage DEMs and Anaglyph-Mode Exploration via the Web. Comput. Geosci. 2012. [CrossRef]

52. Büttner, G.; Feranec, J.; Jaffrain, G.; Mari, L.; Maucha, G.; Soukup, T. The CORINE Land Cover 2000 Project. EARSeL eProceedings 2004, 3, 331-346.

53. Scrinzi, G.; Floris, A.; Clementel, F.; Bernardini, V.; Chianucci, F.; Greco, S.; Michelini, T.; Penasa, A.; Puletti, N.; Rizzo, M.; et al. Models of Stand Volume and Biomass Estimation Based on LiDAR Data for the Main Forest Types in Calabria (Southern Italy). J. Silvic. For. Ecol. 2017. [CrossRef]

54. Mason, D.C.; Cobby, D.M.; Horritt, M.S.; Bates, P.D. Floodplain Friction Parameterization in Two-Dimensional River Flood Models Using Vegetation Heights Derived from Airborne Scanning Laser Altimetry. Hydrol. Process. 2003, 17, 1711-1732. [CrossRef]

55. Nardi, F.; Vivoni, E.R.; Grimaldi, S. Investigating a Floodplain Scaling Relation Using a Hydrogeomorphic Delineation Method. Water Resour. Res. 2006, 42. [CrossRef]

56. Nardi, F.; Annis, A.; Di Baldassarre, G.; Vivoni, E.R.; Grimaldi, S. GFPLAIN250m, a Global High-Resolution Dataset of Earth's Floodplains. Sci. Data 2019, 6, 1-6. [CrossRef] [PubMed]

57. Dodov, B.; Foufoula-Georgiou, E. Generalized Hydraulic Geometry: Insights Based on Fluvial Instability Analysis and a Physical Model. Water Resour. Res. 2004. [CrossRef]

58. Leopold, L.B.; Maddock, T.J. The Hydraulic Geometry of Stream Channels and Some Physiographic Implications; US Government Printing Office: Washington, WA, USA, 1953.

59. Annis, A.; Nardi, F.; Morrison, R.R.; Castelli, F. Investigating Hydrogeomorphic Floodplain Mapping Performance with Varying DTM Resolution and Stream Order. Hydrol. Sci. J. 2019, 64, 525-538. [CrossRef]

60. Nardi, F.; Morrison, R.R.; Annis, A.; Grantham, T.E. Hydrologic Scaling for Hydrogeomorphic Floodplain Mapping: Insights into Human-Induced Floodplain Disconnectivity. River Res. Appl. 2018, 34, 675-685. [CrossRef]

61. Morrison, R.R.; Bray, E.; Nardi, F.; Annis, A.; Dong, Q. Spatial Relationships of Levees and Wetland Systems within Floodplains of the Wabash Basin, USA. J. Am. Water Resour. Assoc. 2018, 54, 934-948. [CrossRef]

62. Scheel, K.; Morrison, R.R.; Annis, A.; Nardi, F. Understanding the Large-Scale Influence of Levees on Floodplain Connectivity Using a Hydrogeomorphic Approach. J. Am. Water Resour. Assoc. 2019, 55, 413-429. [CrossRef] 
63. Annis, A.; Nardi, F. Integrating VGI and 2D Hydraulic Models into a Data Assimilation Framework for Real Time Flood Forecasting and Mapping. Geo-Spat. Inf. Sci. 2019, 22, 223-236. [CrossRef]

64. Hawker, L.; Neal, J.; Bates, P. Accuracy Assessment of the TanDEM-X 90 Digital Elevation Model for Selected Floodplain Sites. Remote Sens. Environ. 2019, 232. [CrossRef]

65. Falorni, G.; Teles, V.; Vivoni, E.R.; Bras, R.L.; Amaratunga, K.S. Analysis and Characterization of the Vertical Accuracy of Digital Elevation Models from the Shuttle Radar Topography Mission. J. Geophys. Res. Earth Surf. 2005. [CrossRef]

66. Piscopia, R.; Petroselli, A.; Grimaldi, S. A Software Package for Predicting Design-Flood Hydrographs in Small and Ungauged Basins. J. Agric. Eng. 2015, 46, 74-84. [CrossRef]

67. Rossi, F.; Villani, P. A Project for Regional Analysis of Floods in Italy. In Coping with Floods; Springer: Dordrecht, The Netherlands, 1994. [CrossRef]

68. Grimaldi, S.; Petroselli, A.; Romano, N. Green-Ampt Curve-Number Mixed Procedure as an Empirical Tool for Rainfall-Runoff Modelling in Small and Ungauged Basins. Hydrol. Process. 2013, 27, 1253-1264. [CrossRef]

69. Grimaldi, S.; Petroselli, A.; Romano, N. Curve-Number/Green-Ampt Mixed Procedure for Streamflow Predictions in Ungauged Basins: Parameter Sensitivity Analysis. Hydrol. Process. 2013, 27, 1265-1275. [CrossRef]

70. NRCS. National Engineering Handbook; NRCS: Washington, WA, USA, 1983.

71. Nardi, F.; Grimaldi, S.; Santini, M.; Petroselli, A.; Ubertini, L. Hydrogeomorphic Properties of Simulated Drainage Patterns Using Digital Elevation Models: The Flat Area Issue. Hydrol. Sci. J. 2008. [CrossRef]

72. Annis, A.; Nardi, F.; Volpi, E.; Fiori, A. Quantifying the Relative Impact of Hydrological and Hydraulic Modelling Parameterizations on Uncertainty of Inundation Maps. Hydrol. Sci. J. 2020, 65, 507-523. [CrossRef]

73. Cobby, D.M.; Mason, D.C.; Davenport, I.J. Image Processing of Airborne Scanning Laser Altimetry Data for Improved River f Lood Modelling. ISPRS J. Photogramm. Remote Sens. 2001, 56, 121-138. [CrossRef]

74. Apollonio, C.; Balacco, G.; Novelli, A.; Tarantino, E.; Piccinni, A.F. Land Use Change Impact on Flooding Areas: The Case Study of Cervaro Basin (Italy). Sustainability 2016. [CrossRef]

75. Hooke, J.M. Variations in Flood Magnitude-Effect Relations and the Implications for Flood Risk Assessment and River Management. Geomorphology 2015. [CrossRef]

76. Notti, D.; Giordan, D.; Caló, F.; Pepe, A.; Zucca, F.; Galve, J.P. Potential and Limitations of Open Satellite Data for Flood Mapping. Remote Sens. 2018. [CrossRef]

77. Mason, D.C.; Horritt, M.S.; Hunter, N.M.; Bates, P.D. Use of Fused Airborne Scanning Laser Altimetry and Digital Map Data for Urban Flood Modelling. Hydrol. Process. 2007. [CrossRef]

78. Pellicani, R.; Parisi, A.; Iemmolo, G.; Apollonio, C. Economic Risk Evaluation in Urban Flooding and Instability-Prone Areas: The Case Study of San Giovanni Rotondo (Southern Italy). Geosciences 2018. [CrossRef]

79. Dottori, F.; Di Baldassarre, G.; Todini, E. Detailed Data Is Welcome, but with a Pinch of Salt: Accuracy, Precision, and Uncertainty in Flood Inundation Modeling. Water Resour. Res. 2013. [CrossRef]

80. Ferrari, A.; Viero, D.P.; Vacondio, R.; Defina, A.; Mignosa, P. Flood Inundation Modeling in Urbanized Areas: A Mesh-Independent Porosity Approach with Anisotropic Friction. Adv. Water Resour. 2019. [CrossRef]

81. Miller, J.D.; Hutchins, M. The Impacts of Urbanisation and Climate Change on Urban Flooding and Urban Water Quality: A Review of the Evidence Concerning the United Kingdom. J. Hydrol. Reg. Stud. 2017. [CrossRef]

(C) 2020 by the authors. Licensee MDPI, Basel, Switzerland. This article is an open access article distributed under the terms and conditions of the Creative Commons Attribution (CC BY) license (http://creativecommons.org/licenses/by/4.0/). 